Mijn ervaring heeft mij echter geleerd dat, hoe vreemd dit ook moge klinken, slechts bij uitzondering verzekeringen worden gesloten welker vorm en inhoud inderdaad aan alle objectief en subjectief te stellen eisen voldoen. Bij de analyse van een lopende verzekeringspositie (welke analyse steeds noodzakelijk is, vóór een juist advies kan worden verstrekt) zijn steeds weer dezelfde lacunes vast te stellen: $E_{r}$ is te weinig of te veel risico gedekt; er wordt te weinig of te veel gespaard (dit laatste vaak wanneer er studieverzekeringen zijn gesloten); $\mathrm{er}$ is te weinig rekening gehouden met nog niet aanwezige, doch in de toekomst waarschijnlijk of zeker intredende wijzigingen in status, vermogen - of inkomstenpositie van de betrokkene; men heeft zich niet voldoende rekenschap gegeven van de fiscale werking der polisconstructie; de gekozen polisvorm beantwoordt gebrekkig aan het beoogde doel e.d.

De eisen waaraan elke voorziening op zichzelf en in verband met het geheel moet worden getoetst, zijn dan ook:

1e. De verzekeringsvorm moet zich geheel aanpassen aan de financiële en sociale omstandigheden, waarin de verzekeringnemer en diens gezin zich bevinden, waarbij tevens rekening is te houden met vooruitzienbare wijzigingen in de toekomst;

2e. De verzekering moet derhalve ook rekening houden met reeds bestaande voorzieningen. Een polis kan alleen volledig worden beoordeeld in het geheel der aanwezige voorzieningen en omstandigheden;

3e. Elke nieuwe, in het geheel der voorzieningen op te nemen polis moet worden getoetst op haar betekenis niet alleen op het ogenblik van afsluiting maar ook bij redelijk te verwachten wijzigingen in het gezin of in de levensomstandigheden;

4e. De verhouding van risico-dekking en spaarelement, bezien in het licht van alle aanwezige voorzieningen, moet rationeel zijn;

5e. De keuze van verzekeringnemer en verzekerde, alsmede de aanwijzing van begunstigden moet op dusdanige wijze geschieden, dat het doel der verzekering op zijn gunstigst en met de geringste kosten wordt bereikt;

6e. De polisconstructie moet de mogelijkheid bieden tot een maximum aan fiscale besparingen, althans leiden tot een minimum aan fiscale nadelen.

Het is duidelijk, dat deze toetsing het best tot zijn recht komt door inschakeling van de zelfstandige, d.w.z. niet van enige verzekeringmaatschappij afhankelijke en behoorlijk voor zijn taak berekende levensverzekeringsadviseur.

Over deze figuur in het volgend artikel.

\title{
DE ONTWIKKELING VAN HET ACCOUNTANTSBEROEP IN DE VERENIGDE STATEN VAN NOORD AMERIKA
}

door Dts M.J. W. J. Eckhardt

In het officiële orgaan van het American Institute of Accountants "Journal of Accountancy" van Januari 1948 komt een opmerkelijk artikel voor over de ontwikkeling van het accountantsberoep in de Verenigde Staten geschreven door John L. Carey. Medegedeeld wordt, dat het American Institute of Accountants goedgekeurd heeft over te gaan tot 
het opstellen van een „Public Information Program" hetgeen de schrijver van harte toejuicht. John L. Carey meent, dat het accountantsberoep thans in een nieuwe faze is getreden: de faze van het contact met het publiek. De kwestie waar het volgens hem om gaat is niet, dat er contact met het maatschappelijk verkeer bestaat, maar eerder hoe de verhoudingen met dat verkeer zullen zijn. Hij constateert, dat het werk van de public accountant niet voldoende wordt begrepen en gewaardeerd; het beroep geniet niet het volle vertrouwen dat de opmerkelijke resultaten rechtvaardigt. Zonder het vertrouwen een handje te helpen zal het maatschappelijk verkeer gemakkelijk de functie van de public accountant gaan onderschatten met het gevolg, dat het beroep geleidelijk wordt ondermijnd. Denkend aan de uitspraak van Abraham Lincoln: „With public opinion nothing can fail; without it nothing can succeed" is hij van mening dat, wil er geen kentering in het beroep komen, een grootscheepse propaganda voor het beroep moet worden opgezet.

$\mathrm{Nu}$ zijn er twee methoden die elkaars uitersten zijn:

A. De conservatieve methode,

Wanneer de public accountant zich waardig en deskundig gedraagt zullen zijn verdiensten worden erkend en zijn diensten zullen worden gewaardeerd.

B. De radicale methode:

Grote geldbedragen zullen moeten worden verzameld om te kunnen adverteren, voor de radio te spreken, literators te honoreren en films te vervaardigen.

De juiste oplossing ziet Carey in een compromis van deze twee methodes.

Het lijkt mij niet overbodig hier te wijzen op de grote gevaren welke zullen ontstaan wanneer het beroep deze richting inslaat.

Indien het inderdaad zo is, dat het maatschappelijk verkeer de resultaten van de functie onderschat, dan kan m.i. deze mentaliteit niet te niet worden gedaan door een propaganda voor het beroep. A priori wordt in het maatschappelijk verkeer aangenomen, dat de accountantsverklaring de zekerheid verschaft die door het verkeer wordt geëist. De functie van de public accountant groeit door de eisen van het verkeer als gevolg van de rationele behoeften. Wanneer in de Verenigde Staten het vertrouwen in de capaciteiten van de public accountant niet zodanig is als men meent te verwachten, dan is blijkbaar de taak bij de functie ten achter gebleven; deze sluit dus niet aan op de behoeften van het verkeer en is dus irrationeel. De redding uit de impasse waarin de Amerikaanse accountant blijkbaar denkt te geraken moet dus niet gezocht worden in een publieke beinvloeding via radio, film en pers, omdat dit eerst recht het wantrouwen zou doen ontstaan, noch door conservatieve beroepsuitoefening, maar door aanpassing van de taak aan de functie van de public accountant, zijnde vertrouwensman van het maatschappelijk verkeer.

\section{Onderschrift}

Het kan zijn nut hebben de ontboezeming van Carey onder de aandacht te brengen van de lezers van dit blad, als een opmerkelijk verschijn sel in de beroepsverhoudingen in de Verenigde Staten. Men houde intussen in het oog, dat wij hier vooralsnog slechts te doen hebben met de uiting van een enkeling, wiens persoonlijke visie geenszins een symptoom behoeft te zijn van een in ruime kring bestaande zienswijze en evenmin een bewijs voor het bestaan van het door Carey gesignaleerde euvel.

Redactie. 